Oliver Gassmann, Patricia Sandmeier, and Christoph H. Wecht (2006)

\title{
Extreme Customer Innovation in the Front-End: Learning from a New Software Paradigm
}

The final version of this manuscript is published in International Journal of Technology Management, 33(1): 42-66.

The final publication is available at www.inderscience.com:

http://www.inderscience.com/info/inarticle.php?artid=8191

DOI: 10.1504/IJTM.2006.008191

http://dx.doi.org/10.1504/IJTM.2006.008191

Please note that differences between this manuscript and the final publication may exist. In case of questions, please contact the corresponding author as indicated below. 


\title{
Extreme Customer Innovation in the Front-End: Learning from a New Software Paradigm
}

\section{Oliver Gassmann, Patricia Sandmeier, and Christoph H. Wecht}

\author{
Institute for Technology Management, University of St. Gallen, \\ Dufourstrasse 40a, 9000 St. Gallen, Switzerland \\ Fax: +41-71-224-7301 E-mail: patricia.sandmeier@unisg.ch
}

Publication accepted - March 2005

\begin{abstract}
The front-end phase of the innovation process constitutes up to two-thirds of the total cost of new product development (NPD). In response to the new open innovation paradigm, new ways to integrate customers' knowledge into the innovation front-end must be explored. In an attempt to learn from analogous situations in which the interface between developers and customers has been managed successfully, this article analyses the Extreme Programming (XP) approach of software engineering. Through its iterative but disciplined probe-and-learn cycles, the approach helps companies effectively develop advanced products with the help of their customers. Using case studies from interviews with R\&D directors of 16 technologyintensive companies, the applicability of successful practices from XP to traditional NPD is analyzed. The authors identify four determinants for front-end management that reside between creativity and resource efficiency. These determinants dictate the potential for front-end effectiveness improvement and enable the maximum amount of knowledge generation and absorption from the customer.
\end{abstract}

Keywords: Innovation process; front-end management; NPD; open innovation; customer integration; knowledge absorption; Extreme Programming; probe and learn process

Reference to this paper should be made as follows: Gassmann, O., Sandmeier, P. and Wecht, C. H. (2005) 'Extreme Customer Innovation in the Front-End: Learning from a New Software Paradigm', Int. J. Technology Management

Biographical notes: Prof. Dr. Oliver Gassmann is professor of technology and innovation management and director at the Institute of Technology Management, University St. Gallen. Before he was responsible for corporate research and advanced development at Schindler, a leading elevator and escalator company, worldwide. The main focuses of his research are industrial innovation and R\&D internationalization.

Patricia Sandmeier is a research associate and Ph.D. candidate at the chair of technology and innovation management at the Institute of Technology Management, University St. Gallen. Her main research focus is managing the innovation front-end in new product development (NPD) and developing novel concepts for early customer integration into the innovation front-end to improve the effectiveness of NPD.

Christoph $\mathrm{H}$. Wecht is also a research associate and Ph.D. candidate at the chair of technology and innovation management at the Institute of Technology Management, University St. Gallen. His main research focus is assessing new approaches to customer integration into the front-end of the innovation process on the basis of the underlying manufacturers' goals and respective customers' roles and contribution. 


\section{Customer Integration into NPD}

\subsection{Early Customer Integration from an Open Innovation Perspective}

Adapting quickly to customers' evolving needs by developing new products entails the challenge of "betting on the right horse" from the very beginning of the R\&D process. Shortened innovation cycles, the fusion of industries, and the resultant rapidly changing environment of market players and business models require more effective innovation activities. And simultaneous budget cutbacks and escalating industrial R\&D costs have forced companies to the understanding that innovation capabilities from outside the company must be exploited better.

Considering these stressed $R \& D$ budgets, as well as the fact that the early phase of the innovation process can consume up to $85 \%$ of the total cost of new product development (NPD) (Buergel and Zeller, 1997; Herstatt and Verworn, 2002), the decision regarding the proper investments must be made as soon as possible to direct the entire value chain of the innovation process toward market needs. Therefore, integrating customers' knowledge from the very first R\&D activities, the so-called innovation front-end, to enrich and ensure the relevance of emergent new products appears as a condition sine qua non.

Researchers and practitioners concordantly recommend that, to reduce the risks of failure and target resource spending more precisely, companies must align their key NPD activities with actual and potential customers (Kohli and Jaworski, 1990; Biemans, 1991; Bacon and Beckman, 1994; Atuahene-Gima, 1995; Murphy and Kumar, 1996; 1997). This integration of customers into the innovation process was discussed to a great extent in the 1980s but gained new recognition during the shift to a new innovation paradigm: open innovation (Chesbrough, 2003). The open innovation paradigm states that the innovation potential of stakeholders outside the company must be captured and has become increasingly important for both practice and theory in the past two years. Out of necessity, companies are tapping the innovation resources and capabilities of customers, suppliers, and other parties that may contribute to NPD and integrating their knowledge into the innovation process from its earliest phases (Hagedoorn and Duysters, 2002; Muller and Välikangas, 2002; Rigby and Zook, 2002; Chesbrough, 2003; Luethje, Lettl et al., 2003; Gassmann, Sandmeier et al., 2004).

Because a significant fraction of innovative products are directly initiated or significantly influenced by the needs and specific requests of customers (Lettl, 2004), this article concentrates on new insights and concepts to better exploit customer knowledge in NPD projects. An impressive approach to the intersection between customers and R\&D is demonstrated by Extreme Programming (XP) in software engineering, in which customers are integrated continuously and from the very beginning in NPD, which enables the company to absorb their knowledge portfolio fully by interactively addressing their current and future needs. With regard to traditional NPD activities in the industrial and consumer goods sectors, can this collaborative XP approach be used to enhance the effectiveness and efficiency of innovation activities?

\subsection{Aims}

Current practices to integrate customers as external innovation resources in the front-end face many difficulties, such as creating an integrative environment for R\&D and customers that connects technical competencies and knowledge about current and future customer needs. For the 
traditional industrial sector, as well as the consumer goods industry, existing research approaches have failed to synthesize the somewhat controversial requirements for managing a performing front-end and integrating customers. Mastering these two management tasks represents the foundation of an integrated front-end concept that increases the overall performance of innovation activities. Although the potential for process improvement in later innovation stages already has been detailed - as the well-described stage gate processes and simultaneous engineering practices

demonstrate - the need for new front-end solutions close to and together with customers remains high.

This article focuses on the determinants of the successful management of customer integration into the innovation front-end, which we derive from an analogy to the innovative XP approach of software development. The XP approach provides an impressive solution at the developercustomer interface: Short development steps with clear tasks, as defined by the customers' needs, allow for short, highly creative process cycles with high learning potential. Using this methodology can increase the effectiveness of software development activities by factors (Beck, 2000). Because there is no single best solution for all projects and companies, we employ a contingency approach to identify XP success factors that can be transformed into determinants for NPD practices by traditional industrial and consumer goods sectors. Through our analysis, we aim to make the following contributions:

1. We define the theoretical requirements for front-end management and its challenges, taking into account the integration of customer knowledge.

2. On the basis of insights into the XP model and its successful front-end practices with customers, we identify existing analogies to XP in the NPD of industrial and consumer goods.

3. From these successful practices in NPD, we derive four principal determinants for active customer integration management during the innovation front-end that can help improve the effectiveness of front-end activities.

\subsection{Research Methodology}

The inductive nature of the intended research requires a qualitative case study approach to attain a thorough understanding of the system (Stake, 1988; Yin, 1994). Current research provides little information regarding a concrete design for an NPD front-end customer integration process, but the analogy to XP opens a new perspective on traditional NPD. Therefore, we study several cases in detail to gain an in-depth understanding of their natural setting, complexity, and context (cf. Punch, 1998).

We analyzed existing literature to explore the new XP software paradigm, but because little is known about the phenomenon in innovation research (the rare literature is limited to practical guidelines), we also conducted interviews with software engineers who have experience with XP projects and often participate actively in an open source community.

To investigate the field of industrial and consumer goods, we applied a multiple case design. In addition, we maximized the differences among selected cases by varying our choice of companies according to their countries and sizes and thereby control for idiosyncratic influences and provide a basis for a future generalization. The chosen companies take active measures to profit from customers' knowledge by trying to turn their early NPD activities into an integrated concept in which they find solutions to absorb external knowledge from the customer directly 
into R\&D. The uncovered similarities in management practices across diverse early customer integration activities indicate that a relationship exists between practice and outcomes (cf. Lynn, Morone et al., 1996).

To permit a comparison to XP, we selected the companies first according to their pioneering efforts in active customer integration and then according to their modular product structure, in which every module can be upgraded independently, which results in relatively low costs for introducing a product enhancement or adding new functionality. The units of analysis for our investigation are innovative R\&D projects for which the customer contributes significantly to the NPD from the project's very start. That is, the customer was intensively consulted by the manufacturer during these projects or even took an active role during the front-end phase of innovation activities.

We collected data during a 2003-2004 research project. The project concentrated on all aspects of early customer integration and investigated the following companies for in-depth case studies: Bayer MaterialSciences, Buchi Labortechnik, Endress +Hauser, Hilti, IVF Hartmann, Leica, Mammut Sports Group, Model, MTU Aero Engines, Philips, Qiagen, Schindler, Sefar, Siemens, SIG Combibloc, and Zumtobel. All companies are based in Germany, Liechtenstein, Switzerland, or The Netherlands, are spread across different industries, and range from small enterprises to large multinationals. We conducted 48 semi-structured research interviews with senior representatives of $\mathrm{R} \& \mathrm{D}$, marketing, and product management, as well as with customers of the companies. The interview data were complemented by desk research and analyses of corporate and annual reports, company presentations, and company journals. In follow-up workshops with the interview partners, we validated our interpretations of our findings with the companies.

\section{Review of Front-End and Customer Integration Literature}

Despite substantial scientific research in NPD, our investigation shows that R\&D managers acknowledge the rarity of successful practice examples for actively managing the innovation front-end. Companies' current attempts tend to concentrate on sequential models and methods known from project management activities in the latter innovation stages. Extensive literature can be found on such linear methods, as well as on the implementation of individual front-end activities such as road mapping, scenario analysis, and creative product idea generation (Conway and McGuinness, 1986; Christensen and Anthony, 2001; Kelley, Littman et al., 2001; Goldenberg, Mazursky et al., 2003; Mauzy and Harriman, 2003). However, difficulties emerge when embedding these models, or stand-alone activities, into the organization because they simply do not reflect the reality of the front-end phase, with its iterative and fuzzy characteristics, nor do they address interfaces with other innovation activities sufficiently. As a consequence, only theoretical circular models allow for an actual course of action during the innovation frontend (Khurana and Rosenthal, 1997; Kim and Wilemon, 2002; Koen, Ajamian et al., 2002). Critiques of these circular, often dynamic, models come from practitioners who express their difficulties in applying and implementing them. Models based on iterative learning cycles, in particular, remain highly abstract and non-transferable to real-life business situations.

An integrated innovation front-end should contain a systematic approach to accessing information from multiple sources, with a special focus on input from outside the company, which would result in more viable future business development projects. Therefore, innovation sources from outside the company must be involved in the front-end to extend the R\&D capacity 
and broaden perspectives toward new product and business opportunities (Bobrowski, 2000; Quinn, 2000; Muller and Välikangas, 2001; Hagedoorn and Duysters, 2002; Muller and Välikangas, 2002; Rigby and Zook, 2002; Sakkab, 2002; Chesbrough, 2003).

As a matter of course, resources for NPD should be amplified from the very beginning of product innovation. Therefore, early customer integration into the innovation front-end represents a promising, though difficult, way to profit from external innovation sources. Recent literature provides a rich body of co-development and customer cooperation examples, though von Hippel's (1986) lead-user approach remains the most important empirically validated concept of early, active customer involvement (Urban and von Hippel, 1988; Kotler, 1999; Dahan and Hauser, 2001; Kohn and Niethammer, 2002; Lilien, Morrison et al., 2002; Thomke and von Hippel, 2002; Ulwick, 2002; von Hippel and Katz, 2002; Sandmeier and Wecht, 2004). In addition, recent advancements regarding user toolkits and early customer integration, enabled by new information and communication technologies, demonstrate the relevance of early customer integration in current business environments (von Hippel, 1986; von Hippel, Thomke et al., 1999; von Hippel, 2001; Herstatt, 2002; von Hippel and Katz, 2002) and hint at how the customer's knowledge as a product user, particularly his or her technological development competence in the business-tobusiness arena, can be used in an institutionalized way during the innovation front-end process.

In turn, investigations of established practices about how to integrate the customer into R\&D activities has provided several managerial implications in terms of the organizational and methodical design of the innovation front-end (Herstatt and Verworn, 2003). Nevertheless, such early integration still involves challenges and controversies. First, an engineer's creativity may be restricted through perceived pressure and control by integrated customers, which would force him or her in technologically undesirable directions. Second, as a result of the potential cultural differences between the customer and R\&D employees, the interface may bear high friction losses; that is, there is no guarantee that the customer's requirements are understood or articulated well (von Hippel and Katz, 2002). Third, early customer integration into NPD often leads to incremental improvements of existing solutions rather than radically new breakthrough products (von Hippel, 1988; Leonard-Barton, 1995; Christensen, 1997). Fourth, a strong focus on the customer might alienate the manufacturer from its inherent core competencies (Lilien, Morrison et al., 2002). Fifth, selecting those customers who can truly contribute (e.g., lead users) is in practice quite challenging. There is no guarantee of finding the right partner, and the consequences of an improper collaboration can be not only harmful but dangerous. Sixth and finally, the integration of customers into the innovation process sometimes means that more time and involvement must be expended (Lilien, Morrison et al., 2002).

Insights from existing literature reveal these challenges of establishing the controversial requirements for the holistic management of the innovation front-end in which the customers' potentials are taken into account. Table 1 gives an overview of some relevant aspects in the literature that pertain to the effective management of customer integration into the innovation front-end. 
Table 1 Requirements for Customer Integration into the Innovation Front-End

\begin{tabular}{|c|c|c|c|}
\hline $\begin{array}{l}\text { Research } \\
\text { Streams }\end{array}$ & Relevant Aspects & $\begin{array}{c}\text { Key Issues/Managerial } \\
\text { Challenges }\end{array}$ & Sample Studies \\
\hline \multirow[t]{2}{*}{$\begin{array}{l}\text { NPD and front- } \\
\text { end }\end{array}$} & $\begin{array}{l}\text { Resource efficiency } \\
\text { through formal } \\
\text { approaches to } \\
\text { manage NPD } \\
\text { projects }\end{array}$ & $\begin{array}{l}\text { - Improve cycle time and } \\
\text { efficiency } \\
\text { - Formal and structured } \\
\text { processes with sequential } \\
\text { steps } \\
\text { - Team organization } \\
\text { throughout NPD } \\
\text { - Early and sharp product } \\
\text { definition } \\
\end{array}$ & $\begin{array}{l}\text { (Cooper and Kleinschmidt, 1988; Cooper, } \\
\text { 1990; Milison, Raj et al., 1992; Cooper and } \\
\text { Kleinschmidt, 1993; Hughes and Chafin, 1996; } \\
\text { McGrath and Akiyama, 1996; Schachtner, } \\
\text { 1999) }\end{array}$ \\
\hline & $\begin{array}{l}\text { Front-end success } \\
\text { factors }\end{array}$ & $\begin{array}{l}\text { - Allowing degrees of freedom } \\
\text { to foster creativity and } \\
\text { innovation } \\
\text { - Detailed customer needs } \\
\text { analysis } \\
\text { - Support of innovation } \\
\text { champions and promoters } \\
\text { - Avoidance of "not invented } \\
\text { here" (NIH) syndrome }\end{array}$ & $\begin{array}{l}\text { Katz and Allen, 1982; Howell and Higgins, } \\
\text { 1990; Khurana and Rosenthal, 1997; Markham } \\
\text { and Griffin, 1998; Cooper, 1999; Hauschildt } \\
\text { and Kirchmann, 2001; Howell and Shea, 2001; } \\
\text { Kim and Wilemon, 2002; Koen, Ajamian et } \\
\text { al., 2002) }\end{array}$ \\
\hline \multirow[t]{3}{*}{$\begin{array}{l}\text { Early customer } \\
\text { integration }\end{array}$} & $\begin{array}{l}\text { Increase in } \\
\text { innovation process } \\
\text { effectiveness }\end{array}$ & $\begin{array}{l}\text { - Widening of market } \\
\text { perspective } \\
\text { - Improve product-market fit } \\
\text { - Quality improvement } \\
\text { - Risk minimization } \\
\end{array}$ & $\begin{array}{l}\text { (Leonard-Barton and Sinha, 1993; Brown and } \\
\text { Eisenhardt, 1995; Atuahene-Gima, 1996; } \\
\text { Lengnick-Hall, 1996; Rigby and Zook, 2002) }\end{array}$ \\
\hline & $\begin{array}{l}\text { Increase in } \\
\text { innovation process } \\
\text { efficiency }\end{array}$ & $\begin{array}{l}\text { - Use of customer knowledge } \\
\text { and resources } \\
\text { - Potential for R\&D cost and } \\
\text { cycle time reduction } \\
\text { - Outsourcing of value } \\
\text { creation modules }\end{array}$ & $\begin{array}{l}\text { (Quinn, 2000; Hagedoorn and Duysters, 2002; } \\
\text { Sakkab, 2002; Thomke and von Hippel, 2002; } \\
\text { von Hippel and Katz, 2002; Chesbrough, } \\
\text { 2003) }\end{array}$ \\
\hline & $\begin{array}{l}\text { Knowledge } \\
\text { generation }\end{array}$ & $\begin{array}{l}\text { - Implicit and explicit } \\
\text { customer knowledge } \\
\text { involved } \\
\text { - Knowledge conversion } \\
\text { and/or acquisition }\end{array}$ & $\begin{array}{l}\text { (von Hippel, 1977; Urban and von Hippel, } \\
\text { 1988; Nambisan, 2002; Thomke and von } \\
\text { Hippel, 2002) }\end{array}$ \\
\hline
\end{tabular}

As we show subsequently, one of the main requirements for an effective front-end is determining how much management discipline, in terms of resource efficiency, is needed. On the one hand, too much discipline, including a strong focus on process management and a rigorous orientation toward customers' demands, endangers the creativity of engineers because it stabilizes the innovation process to the point that every activity becomes part of a bureaucratic routine and the inventive spirit gets lost. On the other hand, too much freedom, such as organizational slack and allowing people to deploy their creativity through technical gimmicks, bears the risk that potentially breakthrough product ideas fail to find a promoter with decision competencies who could advance them to the new product concept. That is, their realization may be left to chance.

Figure 1 illustrates this challenge between creativity and resource efficiency for innovation front-end management. Creativity in the innovation front-end is enabled by organizational slack and an emphasis on people management, which includes, for example, allowing them to focus on 
technical possibilities, detached from the prospects of market success. Resource efficiency, in contrast, is enabled by discipline and an emphasis on process management, in which the market and customer requirements remain constantly in mind. These opposite claims lead to creative tension that must be resolved by adequate front-end management. In Figure 1, the concentrations in the two corners of the cube demonstrate the dependency of the three axes. An effective innovation front-end, which integrates the customer to an optimal extent and profits from that knowledge without restraints on the company, lies between these two extremes. In a similar way, Nambisan (2002: 406) states that "firms need to structure their product development environment such that a fine balance is achieved between overall flexibility (needed to absorb customer contribution) and the focus and direction (needed to ensure product development effectiveness)."

An effective front-end contains elements that enable both creativity and resource efficiency and therefore fulfills even the contrasting requirements within the spectrum of creative tension. Considering the customer and his or her significant contribution to the success of an NPD, the front-end innovation manager must assess his or her role and activities carefully and embed the customer in a way that mobilizes his or her full knowledge.

Figure 1 Strategic Dilemma of Front-End Management

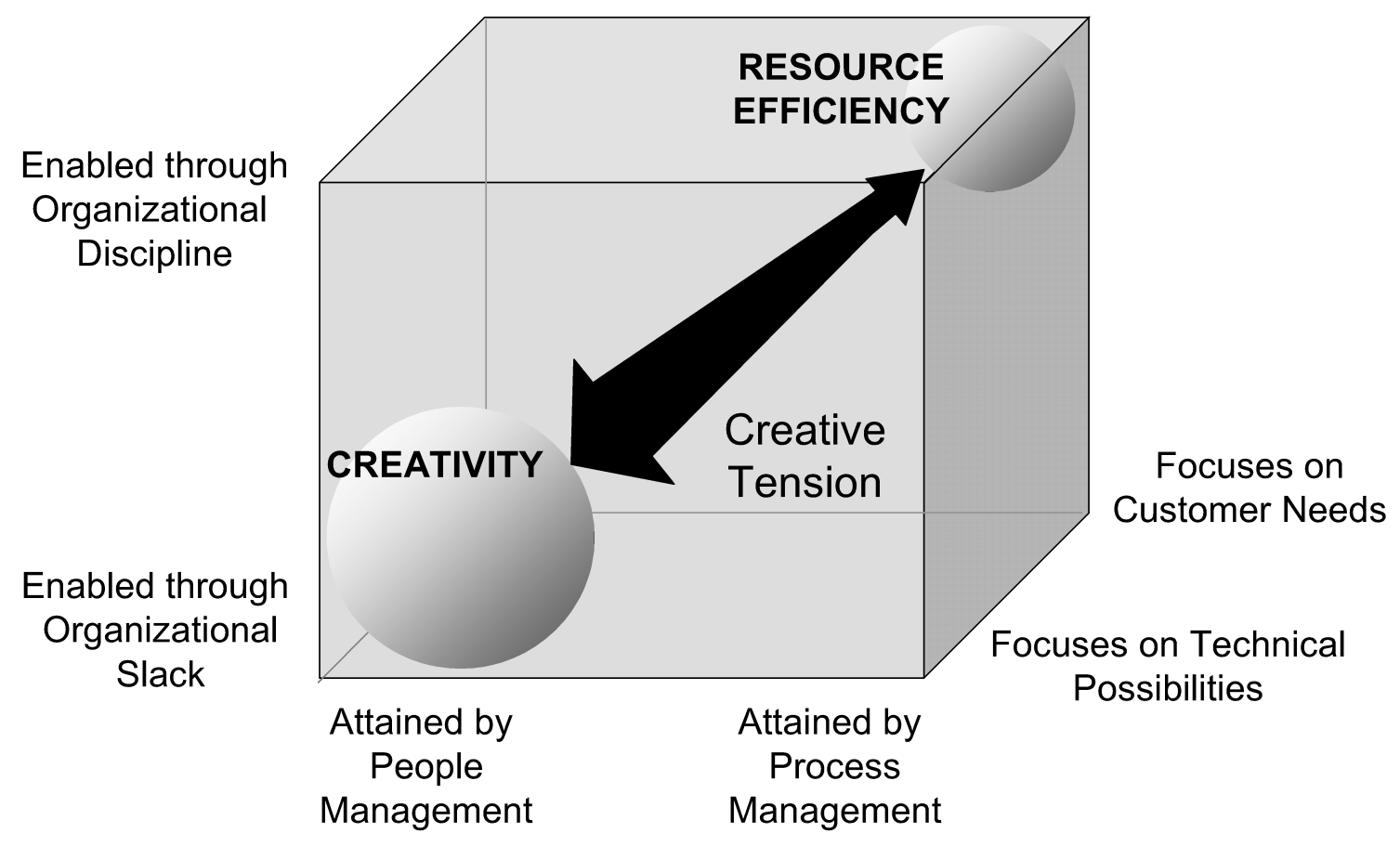

\section{The Analogy to Extreme Programming (XP)}

\subsection{What Is Extreme Programming?}

A software engineering methodology, XP was developed around 1998 by Kent Beck in an attempt to find a new approach to software development that would simplify existing methods to which developers were accustomed (Acebal and Cueva Lovelle, 2002). Eventually, XP became one of 
the most popular disciplines of a group of new procedures that can be summarized as agile software development. Similar to low-overhead methodologies, it is built on the idea that, in environments characterized by rapidly changing requirements, software development is difficult to control. Most important, by ensuring that software engineers focus on smaller units of work, these methods minimize risk. Agile software evolved in the mid-1990s as part of the reaction against resource-heavy methods such as ISO 9000, Rational Unified Process (RUP), and Capability Maturity Model (CMM), which were perceived as bureaucratic, slow, demeaning, and different from the actual path that software engineers tended to follow.

$\mathrm{XP}$ is considered the first established agile software development methodology out of some common tactics popular among computer programmers. The defining characteristic of an XP methodology lies in its incremental, iterative development of sequenced small improvements, which minimize the length of the feedback cycles. Most design activities take place on the fly and incrementally, starting with the simplest solution that could possibly work and only then adding complexity. At the beginning of a NPD project, the customer provides his or her basic needs for a new product, which determines the scope of the first release in XP development. After successfully solving this basic need, which may take up to two months, the first release-which represents an already valuable product - is presented to the customer for feedback. From this basic product, the customer helps define another feature, using a so-called "user story," to refine the product according to his or her needs. On the basis of the most relevant user story, the engineers improve the original solution through changes or add-ons and present the altered product to the customer as the second release. The same procedure takes place for the next release, and so on; each time, four project parameters - time, cost, quality, and scope - are set anew. As a result of these short, manageable iteration loops, whose results each are presented to the customer, planning accuracy is guaranteed because the customer can change his or her mind during the development and deploy knowledge and creativity. Figure 2 illustrates how the new product evolves together with the customer, release by release.

Figure 2 Traditional Software Development Steps Versus XP Development Cycles
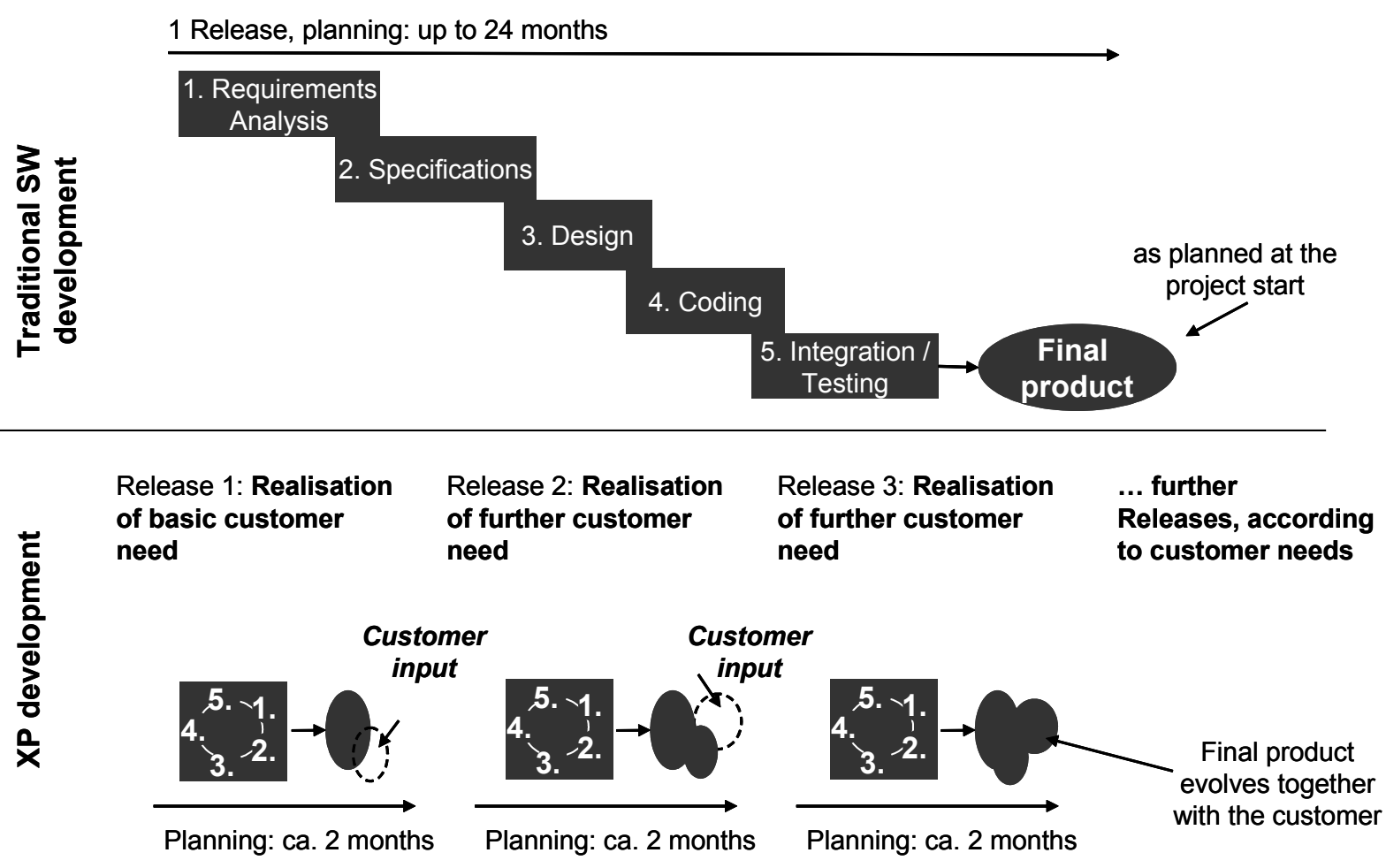
Because of the tight timetable for shortly planned releases, existing pieces of code may need to be reused, which means the definition of specifications, programming, and testing can no longer take place in a sequential way but rather must evolve during a process of probing and learning. To make this somewhat chaotic process work, Beck (2000) describes 12 core practices for XP development (see Table 2). Although Beck did not invent these practices, XP combines them in a new methodology that aims to reciprocally compensate the individual practice's inherent weaknesses.

Table 2 XP Practices (adapted from Beck, 2000)

\begin{tabular}{|c|c|}
\hline XP Practice & Explanation \\
\hline 1. Planning game & $\begin{array}{l}\text { Quickly determine the scope of the next release by combining } \\
\text { business priorities and technical estimates; as reality overtakes the } \\
\text { plan, update the plan. }\end{array}$ \\
\hline 2. Small releases & $\begin{array}{l}\text { Put a simple system into production quickly, then release new } \\
\text { versions on a very short cycle. }\end{array}$ \\
\hline 3. Metaphor & $\begin{array}{l}\text { Guide all development with a simple shared story of how the whole } \\
\text { system works. }\end{array}$ \\
\hline 4. Simplicity in design & $\begin{array}{l}\text { The system should be designed as simply as possible at any given } \\
\text { moment. Extra complexity is removed as soon as it is discovered. }\end{array}$ \\
\hline 5. Testing & $\begin{array}{l}\text { Programmers continually write unit tests, which must run flawlessly } \\
\text { for development to continue. Customers write tests demonstrating } \\
\text { that features are finished. }\end{array}$ \\
\hline 6. Continual integration & $\begin{array}{l}\text { Integrate and build the system many times a day, every time a task } \\
\text { is completed. }\end{array}$ \\
\hline 7. Pair programming & $\begin{array}{l}\text { All production code is written with two programmers at one } \\
\text { machine. }\end{array}$ \\
\hline 8. Collective ownership & Anyone can change any code anywhere in the system at any time. \\
\hline 9. Refactoring & $\begin{array}{l}\text { Programmers restructure the system without changing its behavior } \\
\text { to remove duplication, improve communication, simplify, or add } \\
\text { flexibility. }\end{array}$ \\
\hline 10. Sustainable pace & $\begin{array}{l}\text { Work no more than } 40 \text { hours a week as a rule. Never work overtime } \\
\text { two weeks in a row. }\end{array}$ \\
\hline 11. On-site customer & $\begin{array}{l}\text { Include a real, live user on the team, available full-time to answer } \\
\text { questions. }\end{array}$ \\
\hline $\begin{array}{l}\text { 12. Shared coding } \\
\text { standards }\end{array}$ & $\begin{array}{l}\text { Programmers write all code in accordance with rules emphasizing } \\
\text { communication through the code. }\end{array}$ \\
\hline
\end{tabular}

Practitioners who are experienced in working with XP agree that not every XP practice is imperative for successful NPD. The metaphor, for example, is difficult to apply to many projects because shared stories may not fit the project sufficiently. Instead, a practicable rule is to use simple, nontechnical language that can be understood by everyone, including the customer, to avoid misunderstandings and ambiguities. In addition, the on-site customer imperative often is difficult to fulfill in practice because the customer will not always be the product user, though only the product user has knowledge about relevant user stories, nor will the customer always invest the necessary amount of resources by being present all the time. In these cases, development teams must imagine a pseudo-customer by asking themselves, for every piece of code they produce: "Do I work on something that could be sold to a customer?"

Software development through XP finishes when the customer is satisfied, meaning that he or she does not value any more added features (i.e., user stories). The final product may not look like the product the customer imagined at the beginning, but it perfectly fits his or her needs. "As soon 
as the customers see the first release, they learn what they want in the second release ... or what they really wanted in the first," states XP founder Kent Beck (Beck, 2000). The following practical company example illustrates this XP method.

The information technology department of Schindler, a Swiss elevator company, has successfully applied XP methodology to develop complementary software for several NPD projects. For example, XP has been applied to develop a security access system for an office building. Discussions with the customer highlighted its basic need for regulated access of employees to certain floors in the building. The solution, in the form of a simple pin code system, was defined as a first release and sold to the customer. In examining this release, the customer discovered its need for visitor access control, which was included in the second release. After several releases, the final product emerged as a sophisticated access system that fit the customer's needs exactly, including not only those needs that led to the NPD but also new ones that stemmed from the increasing importance of security systems in large buildings. Schindler's access control system also can be applied to new elevator markets or provided as a software update for already installed elevators.

However, the applicability of XP methodology for NPD is limited to certain types of customer needs. That is, XP can be applied only to R\&D projects that do not consist of complex technical constructs but instead focus on developments that occur close to the interface with the user of the system. At Schindler, for example, XP could not be used to develop the technology for a new elevator concept in which the basic needs still consist of going up and down in a building and opening the doors. But it can be used successfully to develop new functionalities by which the user is directly affected.

\subsection{Lessons from XP for Front-End Customer Integration}

In the terms of this article, XP can be regarded as a solution for the front-end tension between creativity and resource efficiency (see Figure 1), which intensively involves the customer. The structure that XP provides to NPD, in bringing out release after release, demonstrates a high degree of discipline. Within each release, for which chaotic trial-and-error development is allowed, employees can deploy their full creativity, bring in their new ideas, and focus on all technical possibilities. In addition, closeness to the customer's needs is guaranteed because each finished release is presented in the form of a prototype to the customer. This procedure therefore may be viewed as a method to build and disseminate market and technology knowledge rapidly among all stakeholders of the NPD team, including the customer, which collectively advances the project. The XP team, working in a quick and iterative way for each release, receives a constant flow of customer feedback, which steers the project and keeps corrections in line. The team's continuous, small adjustments keep the project on course, on time, and within budget (Crispin, House et al., 2002).

In contrast to the "universal truth" that the cost of change during project development increases exponentially with time, XP methodology claims that a combination of good programming practices (Table 2) can reverse this curve. Therefore, NPD based on an evolutionary progress emphasizes both the management of a rigid development process and the people or users. Developers and customers both are stimulated by the evolving product, visible as a release or prototype every few months. This early material presence catalyzes new ideas and knowledge that can be integrated into the product and, in turn, may even cause the exploration of novel customer needs. 
The most important advantage of XP lies in the likelihood that it will improve project profitability because of its frequent cost and return control. Therefore, the number of development projects that lead to failures in the market can be reduced significantly. Furthermore, resource investments are lowered because risk avoidance measures, such as those during the specification phase at the beginning of regular software development projects, are no longer necessary. Finally, as a result of the short planning horizon for each development portion, developers are aware of the overall project goal, which contributes significantly to their motivation and closeness to the markets' needs.

However, critics charge that an agile software development method such as XP fails to provide an adequate level of structure and necessary documentation. In addition, few companies have organizational structures that enable the application of XP, which means that significant changes are need to adopt these practices effectively. To establish an XP environment, a huge reorganization of processes and cultural issues is needed.

\subsection{Determinants of Integrative Front-End Management of Industry and Consumer Goods}

Insights from the XP method raise the following question: Can the functionality and practices that render this software development methodology successful be applied to the development of traditional industrial and consumer goods? To investigate this matter, we study whether analogies to XP practices can be identified among successful NPD activities by industrial and consumer goods firms. In the following sections, we provide case examples of companies that actively have integrated their customers into their front-end activities to exemplify some analogies to XP. From these analogies, we derive four determinants of the potential for improving front-end activities, according to the lessons from XP: separability of customers needs, NPD process modularity to enable disciplined sequencing development phases, applicability of cross-functional teams in NPD, and iterative R\&D project steering and planning.

\section{NPD in Specialized High-Tech Industries}

Buchi Labortechnik, an innovation leader in the field of rotary evaporators for laboratory equipment and new products that serve drug development research labs, achieves $20 \%$ of it sales from products less than a year old. Its customers' needs are diverse. Modular product architectures thus might ensure that this complexity is manageable even for products for which different variations are required.

The potential for product innovations in most cases stems from customer requests for a solution with a specific product requirement (e.g., processes must take place in a specific temperature environment. For Buchi, the challenge of such customer-initiated product ideas lies in clarifying the representativeness of these special customer wishes to other customers. Single solutions that do not correspond to an attractive customer field in terms of buying power must be avoided to minimize the common NPD risk that realized product ideas simply cannot be sold in the marketsometimes even not to the customer for whom they were developed.

Buchi faces this challenge by trying to obtain financial commitments for a new product or prototype before investments are taken in hand. Similarly, XP alleviates the risk of a lack of sales by setting the cost parameter for every release or prototype with the initiating customer. In addition, this financial tie improves customers' willingness to discover new product values and provide qualified feedback. 
Also similar to XP methodology, Buchi bring an early prototype to the customer's site during an $\alpha$-test. While the customer handles the new functionalities, R\&D employees absorb the articulated feedback, as well as unarticulated areas of improvement that may become evident from the difficulties the customer encounters while using the prototype. Therefore, similar to the XP small releases practice, the customer receives a functional, testable first release or prototype that leads to the final delivery of the developed product. This step is useful for two reasons. First, by keeping prototypes simple and functional, the development team avoids the "big bang" syndrome, or the difficult attempt to integrate several important customer requirements near the end of the project. Second, the development team always can provide a functional version of the product to the customer, which influences their confidence in the development of the product overall. As XP demonstrates, the customer can use the prototype to give feedback about the project's progress, which can inspire additional product functionalities, or user stories, for the development team's consideration.

In this way, the customer's feedback can be built into the new product concept early. If not limited by exclusivity agreements, Buchi aims to get feedback about the relevance of and sales expectations for its new product from not only the customer that initiated the development but also other customers that may stand out because of their innovative needs. Thus, for the $\beta$-test of the first series, the improved new product is presented to a broader number of customers, which again can lead to marginal new product adjustments.

\section{NPD in Highly Modular Consumer Goods Industries}

IVF Hartmann, a Swiss subsidiary company of the Hartmann Group, one of Europe's leading health care companies that offers a broad range of medical hygiene and consumer products, is about to launch a new, highly innovative bandage that provides a cooling effect. The product idea stemmed from an R\&D employee and was reconsidered from the idea database because its business customer $S U V A$, a Swiss insurance and rehabilitation company considered a lead user, asked for new and innovative products to launch its new campaign. The bandage represents an immediate solution for work or sport injuries for which sustaining and cooling effects are needed at the same time but traditional cooling pads are not available.

The product was developed in an iterative way. Comparable to XP methods, prototypes were presented regularly to the customer to integrate its feedback. For the package design and fastener, for example, the customer was able to express its precise expectations about the way they should look only when it had an actual early prototype of the new bandage. IVF Hartmann could allow for such needs during the very early NPD phase, when integration costs remained low. In addition, the R\&D department tested new materials to fulfill the requirement that the bandage be non-oxidizing in wet environments. To provide the next prototype quickly in response to these requests, the $R \& D$ team also considered creative solutions from other technical disciplines. This search for existing solutions in other applications fields is highly recommended by the XP process to maintain high-speed release development. In the case of the cooling bandage, the development steps, or releases, were quick because the development team did not engage in research to develop new components but instead chose adequate ones from existing products in the market. On the basis of the customer's reaction to the next prototype, IVF Hartmann came up with a blue colour for the bandage to signal and emphasize its cooling effect. This blue colour represents an eyecatcher that contributes significantly to the product's market success.

The case of IVF Hartmann also can be considered an example of how NPD can proceed by continually confronting the customer with an evolving prototype. In terms of analogies to XP 
practices, the following elements work: Because the customer continually is consulted by a project team that includes one person from marketing and sales $(M \& S)$, one from $R \& D$, and one from product management, they play a spontaneous planning game. The development team engages in a planning process with the customer, during which it determines which user stories will be implemented in the next release. Thus, this procedure delivers a short-term schedule to which every person involved in the next step in the NPD development is committed. As a consequence, for example, unrealistic promises from M\&S about technical feasibilities can be avoided because the developers immediately can interfere. Furthermore, engineers learn directly from the customer what it actually wants, which eliminates translation errors that can occur when knowledge must travel across many different departments.

\section{New Product Development in Integrated Systems of High-Tech Industries}

One Swiss company that performs well in R\&D project management is Leica Geosystems. Its core activities lie in surveying technology, visualization and modeling of space-oriented information with an R\&D-focus on hardware (e.g., electronics, construction), and software. Investments in innovation activities amount to $11 \%$ of its sales. During its organizational, topdown redesign to transform itself from a hierarchy to a process orientation of the whole organization, it evolved from functional silos to customer-oriented rugby teams. In addition to establishing cross-functional teams, it identified the need for iterative project planning and control. In response, it set sub-milestones in the milestone process to control and shorten its development cycles. A clear result, rather than task, orientation made employees aware of the final product to be delivered to the customer. At the same time, project modularization and downsized work packages resulted in more transparency, greater speed, and better handling.

To identify new products that may address unused customer segments, the company places its strategic focus on front-end activities. This focus also occurs for its mining business, in which Leica has been active for a short time due to its competence in surveying technologies. In the mining machine industry, Leica develops machines according to customers' specific wants and thereby builds early prototypes for every extension in functionality, such as additional sensors, presented to the customer.

In line with the XP approach, the company captures and integrates existing elements from other application fields or even other industries to fulfill customer requirements with a simple prototype. Therefore, these prototypes tend not to be manufactured with high quality materials but rather represent a conglomerate of technical gadgets used in other fields, combined into an existing product concept. The result represents a mock-up of the final mining machine rather than a working prototype. However, it is sufficient to demonstrate to the customer how its requests for a novel product might be realized. Consequently, customer feedback can be collected without significant prior NPD investments, and the prototypes can be iteratively refined on the basis of this feedback.

In this example, we find an application of the simplicity in design practice from XP. The NPD efforts continue only to the point that they enable the consideration of the latest user story or customer request. According to this simple design of the first prototypes, the collective ownership practice from XP also can be identified. That is, any member of the development team may work on any subsystem in the early phase, because development work within the module architecture is not necessary at that point. Therefore, knowledge about all the modules is spread to the entire team, which counteracts the danger of single modules being dependent on single experts. 
In summary, our consideration and comparison of these insights in NPD practices reveals that many existing front-end activities can be compared to the experimental XP approach of continuously confronting the customer with product releases by incrementally adding new functionalities that match the customers' needs. This method applies to consumer goods as well as industrial goods that traditionally have more complex product architectures.

To synthesize the examples, we note that the companies investigated developed their products by probing potential product solutions using early versions of the products, learning from the probes, and probing again. What makes this process especially valuable is that customers' knowledge can be integrated through continuous feedback after every probing step. Although early prototype customers and M\&S staff without deep technical knowledge may be able to appreciate the value of a new product, they only realize what the new product is about when they see clinical evidence that it works. Furthermore, the full creativity potential generally is deployed fully only when a person observes something that peaks his or her interest. This evolution during NPD similarly has been described by (Lynn, Morone et al., 1996) as the "probe-and-learn process," which they describe as follows: "the initial product is not the culmination of the development process but rather the first step, and the first step in the development process was in and of itself less important than the learning and the subsequent, better-informed steps that followed. The approach at work in these cases might best be described as probing and learning."

The probe-and-learn theory indicates that, during innovation front-end activities, it is impossible to predict which product eventually will be successful or at what price, for whom, when, and where it will be offered. Because the process is so long and dynamic, the market and technology for a new product may look entirely different at the end of the process than it did at the beginning (Lynn, Morone et al., 1996). Therefore, the product must evolve in a disciplined way to allow for the absorption of changes during development; this process even might be viewed as a vehicle to identify the end target together with the customer.

From these insights into companies' current NPD activities, which strongly resemble XP practices, we derive the following determinants, summarized in Figure 3, for the holistic management of the innovation front-end:

1. Separability of customer needs: The more easily a customer's want can be portioned, prioritized, and therefore continually integrated in the form of user stories, the more powerful an evolutionary NPD process becomes. This process enables a focus on both technical feasibility and customer needs. According to the XP planning game practice, the development team performs an estimating process, though which it determines which user stories will be implemented in the next release, and delivers a short-term schedule for when the next feature of the new product will be completed.

2. NPD process modularity to enable disciplined sequencing development phases: The more a development process can be split into small portions of iterative, even chaotic learning processes - each of which results in a prototype module that can be presented to the customerthe more a combination of creative and resource-efficient elements in the innovation front-end is possible. This combination also results in strong deadline reliability, despite the continuous integration of customer knowledge and without killing the engineer's creativity. According to the XP principle of small releases and simplicity in design practices, it is possible to avoid execution failures, chronic time pressure, uncontrolled development slacks, and, in turn, extended delays of the throughput time.

3. Applicability of cross-functional teams in NPD: The involvement of people from both R\&D and 
$M \& S$ in the interaction with customers ensures task relevance for engineers on the technical side and task feasibility for those on the marketing side. Because a project finally depends on persons and their commitment, the synthesis of people and process management can be achieved best through assigning high result responsibility for the final product to each team member. This determinant echoes the XP collective ownership and pair programming practices. Transparency is required for the processes, roles, and obligations of all employees.

4. Flexible R\&D project steering and planning: The fourth determinant is the degree to which it is possible, within the R\&D organization, to adjust resources according to an evolving project. Because the iterative development approach complicates long-term budgeting and resource planning considerably, an NPD approach that follows XP methodology is appropriate when there is a high degree of freedom in project steering and planning. This consideration of resource deployment in an iterative R\&D process mirrors the need for collective ownership in XP. Employees must be able not only to advance a project in their small field of expertise but also to contribute in a flexible way to the broad range of product specifications required by the customer.

Figure 3 Determinants of the Applicability of an Iterative NPD in the Front-End

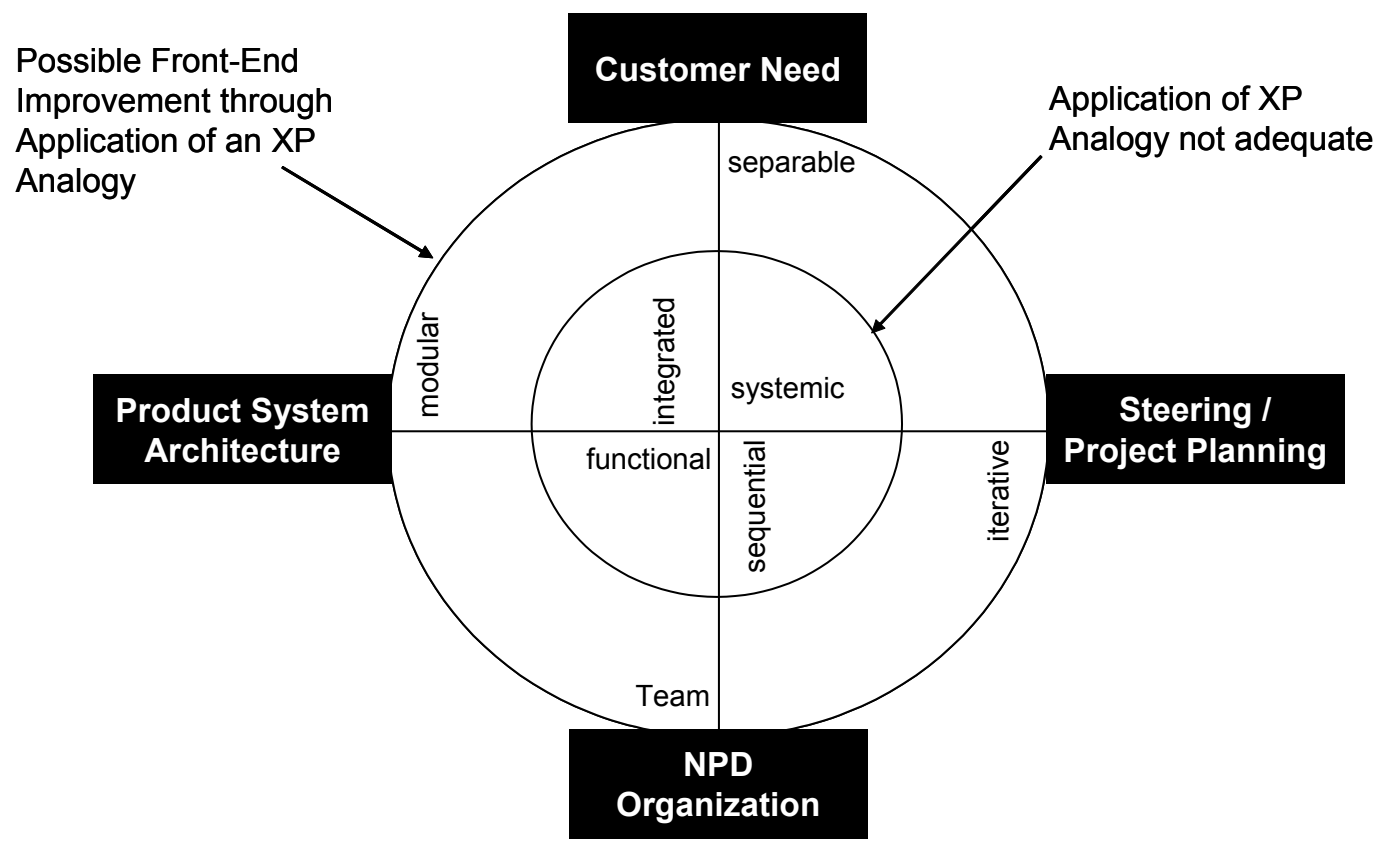

What becomes evident from the XP methodology and the company examples is that probing and learning is anything but a process of blind trial and error. Rather, it represents a process of experimental design and exploration that must take place between the customer and the development team in the context of balanced front-end management between creativity and resource efficiency, as we depict in Figure 1. Using these findings, further research should investigate which products and industries fit within these first NPD determinants, derived from analogies to XP, and, as a consequence, how the determinants might maximize knowledge absorption from customers during and between early prototypes. 


\section{Conclusion}

The purpose of this article was to investigate whether analogies from XP for software development can be drawn for managing the innovation front-end to enable the successful integration of the customer. Our goal was to explore how determinants of customer integration and front-end management might be derived from precise XP practices. By exploring a diverse set of successful cases, we demonstrate that the iterative probing-and-learning XP process is part of modern successful development practices for traditional industrial and consumer goods. Companies consult selected customers with an early version of the product, learn from their feedback, modify the product on the basis of what they learn, and then try again. Therefore, significant potential for improving the effectiveness of innovation front-end activities lies in the systematization of an explorative probe-and-learn approach. In this way, development becomes a process of successive approximation, probing and learning again and again, each time striving to take a step closer to the winning combination of technical feasibility and market needs.

However, this analysis also raises more questions than it puts to rest. First, more effort must attend to the distinction between industrial and consumer goods. In particular, further research should reveal whether more XP practices, such as the planning game and small releases, might be applied beneficially to product development. To analyze continual integration, research also should investigate refactoring and testing practices more deeply.

Other issues of special interest include how platform management and rapid prototyping could be used as vehicles to attain a holistic concept of customer integration in an effective innovation front-end. Answers to this and other questions require further analyses; in this vein, we summarize our current findings and some further research areas in Figure 4.

Figure 4 Overview: XP Lessons

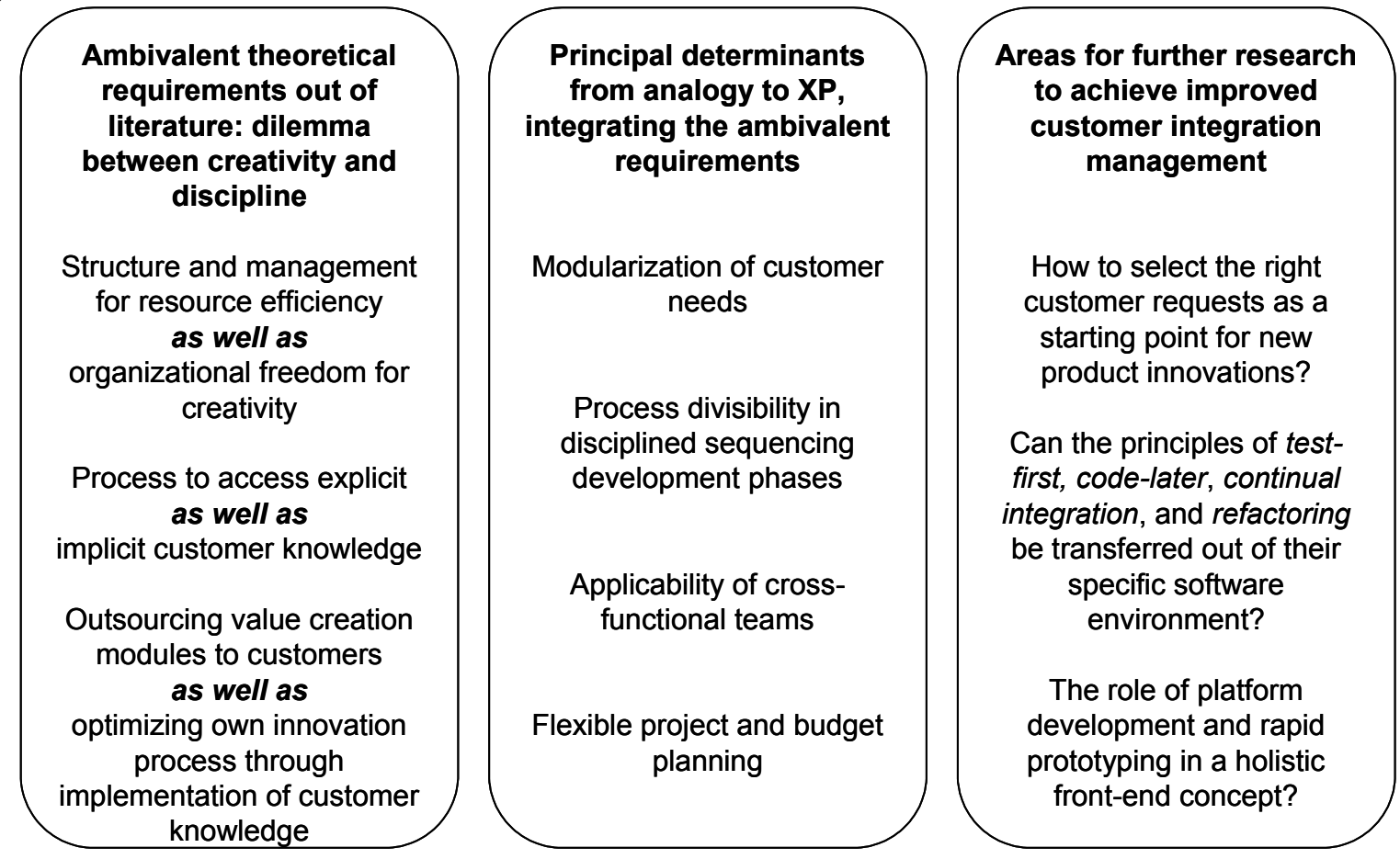

We have learned from XP that an effective innovation front-end, which absorbs customer knowledge in the most efficient way, requires a different NPD methodology based on the logic of 
experimentation. We assume that this analogy to XP can be applied not only to incremental NPD, such as line extensions, but also to radically new products and even new product platforms. To enhance the effectiveness of early innovation activities, this process enables a company to absorb its customers' explicit and implicit knowledge, which provides extremely valuable guidance for steering the NPD toward future customers needs. However, the significant difficulty of this approach remains the uncertainty, common to any customer integration approach, about whether the right customer has been consulted.

For now, one clear conclusion is evident: Looking at the innovation front-end through the lens of XP captures a vision of highly effective product innovation through integrating technical and market knowledge derived directly from the customer. This article demonstrates that though the problem of customer integration into the innovation front-end is well understood in principle, wide gaps of unexploited NPD potential remain. Many starting points for additional determinants and hypotheses have been shown, and further empirical research that extends this study will help close the gap. 


\section{References}

Acebal, C. F. and J. M. Cueva Lovelle (2002). "A new method of software development: eXtreme programming." Informatik(2): 5-9.

Atuahene-Gima, K. (1995). "An exploratory analysis of the impact of market orientation on new product performance." Journal of Product Innovation Management 12(4): 275-293.

Atuahene-Gima, K. (1996). "Market orientation and innovation." Journal of Product Innovation Management 13(5): 456-457.

Bacon, G. and S. Beckman (1994). "Managing product definition in high-technology industries: A pilot study." California Management Review 36(3): 32.

Beck, K. (2000). eXtreme programming eXplained - embrace change. New York, AddisonWesley.

Biemans, W. G. (1991). "User and third-party involvement in developing medical equipment innovations." Technovation 11(3): 163-182.

Bobrowski, P., E. (2000). "A framework for integrating external information into new product development: Lessons from the medical technology industry." Journal of Technology Transfer(25): 181-192.

Brown, S. L. and K. M. Eisenhardt (1995). "Product development: Past research, present findings, and future directions." Academy of Management Review 20(2): 343.

Buergel, H. D. and A. Zeller (1997). "Controlling kritischer Erfolgsfaktoren in der Forschung und Entwicklung." Controlling 9(4): 218-225.

Chesbrough, H. W. (2003). "The era of open innovation." MIT Sloan Management Review 44(3): 35.

Christensen, C. M. (1997). The innovator's dilemma. Boston, Harvard Business School Press.

Christensen, C. M. and S. D. Anthony (2001). What's the BIG idea? HBS case.

Conway, H. A. and N. W. McGuinness (1986). "Idea generation in technology-based firms." Journal of Product Innovation Management 3(4): 276-291.

Cooper, R. G. (1990). "Stage-gate systems: A new tool for managing new products." Business Horizons 33(3): 44-54.

Cooper, R. G. (1999). "The invisible success factors in product innovation." Journal of Product Innovation Management 16: 115-133.

Cooper, R. G. and E. J. Kleinschmidt (1988). "Resource allocation in the new product process." Industrial Marketing Management 17(3): 249.

Cooper, R. G. and E. J. Kleinschmidt (1993). Major new p: What distinguishes the winners in the chemical industry? Journal of Product Innovation Management, Blackwell Publishing Limited. 10: 90-111.

Crispin, L., T. House, et al. (2002). "The need for speed: Automating acceptance testing in an XP environment." Informatik(2): 10-16.

Dahan, E. and J. R. Hauser (2001). Product development - managing a dispersed process. Handbook of Marketing. B. A. Weitz and R. Wensley. London, Sage: 179-222.

Gassmann, O., P. Sandmeier, et al. (2004). "Innovationsprozesse: Öffnung statt Alleingang." io new management (1-2): 22-27.

Goldenberg, J., D. Mazursky, et al. (2003). "Finding your innovation sweet spot." Harvard Business Review 81(3): 120.

Hagedoorn, J. and G. Duysters (2002). "External sources of innovative capabilities: The preferences for strategic alliances or mergers and acquisitions." Journal of Management Studies 39(2): 167. 
Hauschildt, J. and E. Kirchmann (2001). "Teamwork for innovation - the 'troika' of promotors." $R$ \& D Management 31(1).

Herstatt, C. (2002). Suchfelder für radikale Innovationen gemeinsam mit Lead Usern erschliessen. Verkauf. S. Albers, V. Hassmann and T. Tomczak. Düsseldorf, Symposion.

Herstatt, C. and B. Verworn, Eds. (2002). Bedeutung und Charakteristika der frühen Phasen des Innovationsprozesses. Management der frühen Innovationsphasen - Grundlagen Methoden - Neue Ansätze. Wiesbaden, Gabler.

Herstatt, C. and B. Verworn (2003). Management der frühen Innovationsphasen - Grundlagen Methoden - Neue Ansätze. Wiesbaden, Gabler.

Howell, J. M. and C. A. Higgins (1990). "Champions of technological innovation." Administrative Science Quarterly 35(2): 317.

Howell, J. M. and C. M. Shea (2001). "Individual differences, environmental scanning, innovation framing, and champion behavior: key predictors of project performance." Journal of Product Innovation Management 18: 15-27.

Hughes, G. D. and D. C. Chafin (1996). Turning new product development into a continuous learning process. Journal of Product Innovation Management, Blackwell Publishing Limited. 13: 89-104.

Katz, R. and T. J. Allen (1982). "Investigating the not invented here (NIH) syndrome: A look at the performance, tenure , and communication patterns of $50 \mathrm{R} \& \mathrm{D}$ project groups." $R \& D$ Management 12(1): 7-19.

Kelley, T., J. Littman, et al. (2001). The art of innovation: Lessons in creativity from deo, America's leading design firm. New York, Doubleday.

Khurana, A. and S. R. Rosenthal (1997). "Integrating the fuzzy front end of new product development." MIT Sloan Management Review Vol. 38(Issue 2): 18p.

Kim, J. and D. Wilemon (2002). "Focusing the fuzzy front-end in new product development." $R \& D$ Management 32(4): 11.

Koen, P. A., G. M. Ajamian, et al. (2002). Fuzzy front end: Effective methods, tools, and techniques. PDMA Toolbook for New Product Development. P. Belliveau, A. Griffin and S. Somermeyer. New York, John Wiley and Sons: 5-35.

Kohli, A. K. and B. J. Jaworski (1990). "Market orientation: The construct, research propositions, and managerial implications." Journal of Marketing 54(2): 1.

Kohn, S. and R. Niethammer (2002). Aufgabengerechte Kundeneinbindung im Innovationsprozess. Das innovative Unternehmen. B. e. al. Düsseldorf, Symposion.

Kotler, P. (1999). Kotler on marketing: How to create, win, and dominate markets. New York, The Free Press.

Lengnick-Hall, C. A. (1996). "Customer contributions to quality: A different view of the customer-oriented firm." Academy of Management Review 21(3): 791-810.

Leonard-Barton, D. and D. K. Sinha (1993). Developer-user interaction and user satisfaction in internal technology transfer. Academy of Management Journal, Academy of Management. 36: 1125.

Leonard-Barton, D. E. (1995). Wellsprings of knowledge - building and sustaining the sources of innovation. Boston, MA, Harvard Business School Press.

Lettl, C., Ed. (2004). Die Rolle von Anwendern bei hochgradigen Innovationen. Forschungs/Entwicklungs-/Innovations-Management. Wiesbaden, Gabler Edition Wissenschaft.

Lilien, G. L., P. D. Morrison, et al. (2002). "Performance assessment of the lead user ideageneration process for new product development." Management Science Vol. 48(Issue 8): $18 \mathrm{p}$. 
Luethje, C., C. Lettl, et al. (2003). "Knowledge distribution among market experts: A closer look into the efficiency of information gathering for innovation projects." International Journal of Technology Management 26(5/6): 561-577.

Lynn, G. S., J. G. Morone, et al. (1996). "Marketing and discontinuous innovation: The probe and learn process." California Management Review 38(3): 8.

Markham, S. K. and A. Griffin (1998). "The breakfast of champions: Associations between champions and product development environments, practices and performance." Journal of Product Innovation Management 15(5): 436.

Mauzy, J. and R. A. Harriman (2003). Creativity, Inc: Building an Inventive Organization, HBS Press.

McGrath, M. E. and C. L. Akiyama (1996). PACE: An integrated process for product and cycle time excellence. Setting the PACE in Product Development. M. E. McGrath. Boston, Butterworth and Heinemann.

Milison, M. R., S. P. Raj, et al. (1992). A survey of major approaches for accelerating new product development. Journal of Product Innovation Management, Blackwell Publishing Limited. 9: 53-69.

Muller, A. and L. Välikangas (2001). Extending innovation beyond the corporate boundary, Paper presented at Strategic Management Society Annual Conference, San Francisco.

Muller, A. and L. Välikangas (2002). "Extending the boundary of corporate innovation." Strategy and Leadership 30(3): 4 - 9.

Murphy, S. A. and V. Kumar (1996). "The role of predevelopment activities and firm attributes in new product success." Technovation 16(8): 431.

Murphy, S. A. and V. Kumar (1997). "The front end of new product development: A Canadian survey." R\&D Management 27(1): 5.

Nambisan, S. (2002). "Designing virtual customer environments for new product development: Toward a theory." Academy of Management Review 27(3): 392.

Punch, K. F. (1998). Introduction to social research - quantitative and qualitative approaches. London, SAGE Publications.

Quinn, J. B. (2000). "Outsourcing innovation: The new engine of growth." MIT Sloan Management Review 41(4): 13-28.

Rigby, D. and C. Zook (2002). "Open-market innovation." Harvard Business Review 80(10): 8089.

Sakkab, N. Y. (2002). "Connect \& develop complements research and develop at P\&G." Research Technology Management 45(2): 38-45.

Sandmeier, P. and C. H. Wecht (2004). "Von der Kundenorientierung zur Kundenintegration." Technische Rundschau 96(4): 31-33.

Schachtner, K. (1999). "Kommunikations- und Informationsstrukturen für die Planung marktgerechter Produktinnovationen." Information Management \& Consulting 14(3): 8189.

Stake, R. E. (1988). Case study methods in educational research: Seeking sweet water. Complementary Methods for Research in Education. R. Jaeger. Washington DC, American Educational Research Association: 253-300.

Thomke, S. and E. von Hippel (2002). "Customers as innovators: A new way to create value." Harvard Business Review Vol. 80(Issue 4): 8p.

Ulwick, A. W. (2002). "Turn customer input into innovation." Harvard Business Review Vol. 80(Issue 1): p91, 7p. 
Urban, G. L. and E. von Hippel (1988). "Lead user analyses for the development of new industrial products." Management Science 34(5): 569.

von Hippel, E. (1977). "Transferring process equipment innovations from user-innovators to equipment manufacturing firms." $R$ \& D Management 8(1): 13-22.

von Hippel, E. (1986). "Lead users: A source of novel product concepts." Management Science 32(7): $791-805$.

von Hippel, E. (1988). The sources of innovation. New York, Oxford University Press.

von Hippel, E. (2001). "Innovation by user communities: Learning from open-source software." MIT Sloan Management Review 42(4): 82.

von Hippel, E. and R. Katz (2002). "Shifting innovation to users via toolkits." Management Science 48(7): 821.

von Hippel, E., S. Thomke, et al. (1999). "Creating breakthroughs at 3M." Harvard Business Review 77(5): 47.

Yin, R. K. (1994). Case study research: Design and methods, Sage Publications. 